American University Washington College of Law

Digital Commons @ American University Washington College of

Law

Working Papers

Works

2019

The User Rights Database: Measuring the Impact of Copyright

Balance

Sean Flynn

Michael Palmedo

Follow this and additional works at: https://digitalcommons.wcl.american.edu/fac_works_papers

Part of the Intellectual Property Law Commons 


\section{THE USER RIGHTS DATABASE \\ Measuring the Impact of Copyright Balance}

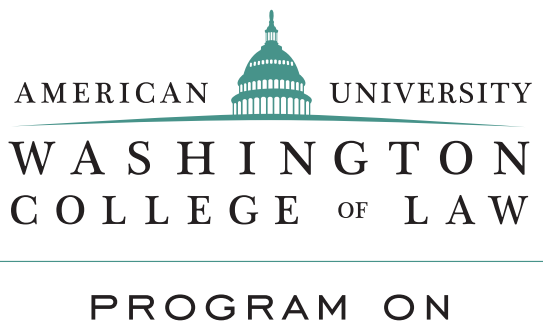

INFORMATION JUSTICE AND

INTELLECTUAL PROPERTY 
WE FIND:

- MORE OPEN USER RIGHTS ENVIRONMENTS ARE ASSOCIATED WITH HIGHER FIRM REVENUES IN INFORMATION INDUSTRIES, INCLUDING SOFTWARE AND COMPUTER SYSTEMS DESIGN.

- MORE OPEN USER RIGHTS ENVIRONMENTS ARE NOT ASSOCIATED WITH HARM TO INDUSTRIES KNOWN TO RELY UPON COPYRIGHT PROTECTION, SUCH AS PUBLISHING AND ENTERTAINMENT.

- RESEARCHERS IN COUNTRIES WITH MORE OPEN USER RIGHTS ENVIRONMENTS PRODUCE MORE SCHOLARLY OUTPUT AND MORE HIGH-QUALITY OUTPUT. 


\title{
THE USER RIGHTS DATABASE: MEASURING THE IMPACT OF COPYRIGHT BALANCE
}

\author{
Sean Flynn and Michael Palmedo*
}

\author{
Version 1.0 - Comments welcome
}

\section{Abstract}

nternational and domestic copyright law reform around the world is increasingly focused on how copyright user rights should be expanded to promote maximum creativity and access to knowledge in the digital age. These efforts are guided by a relatively rich theoretical literature. However, few empirical studies explore the social and economic impact of expanding user rights in the digital era. One reason for this gap has been the absence of a tool measuring the key independent variable - changes in copyright user rights over time and between countries. We developed such a tool, which we call the "User Rights Database."This paper describes the methodology used to create the Database and the results of empirical tests using it. We find that all of the countries in our study are trending toward more open copyright user rights over time, but the wealthy countries in our sample are about thirty years ahead of developing countries on this measure. We find evidence of benefits that more open copyright user rights generate, including the development of high technology industries and scholarly publication. We do not find evidence that opening user rights causes harm to revenue of copyright intensive industries like publishing and entertainment.

\footnotetext{
- Invaluable research assistance was provided by Amber Barreda, Summer Benson, Brooke Friedman, and numerous other PIJIP fellows. We owe an expression of extreme gratitude to the members of the Global Expert Network on Copyright User Rights who contributed substantial time and expertise to this project, including Beatriz Busaniche, Kimberlee Weatherall, Enyinna S. Nwauhce, Allan Rocha de Souza, J. Carlos Lara, Hong Xue, Marcela Palacio-Puerta, Taina Pihlajarinne, Anette Alén-Savikko, Shamnad Basheer, Pankhuri Agarwal, Tatsuhiro Ueno, Ayuko Hashimoto, Heesob Nam, Marco Caspers, Miguel Morachimo, Teresa Nobre, Daniel Seng, David Tan, Zuzana Adamová, Caroline Ncube, Simon Schlauri, Maksym Naumko, Andriy Bichuk, Rami Olwan, Peter Jaszi, Nhan T.T. Dinh, Ahmed Abdel Latif, Lila Bailey, Denis Barbosa, Lionel Bentley, Michael Birnhack, Carolyn Botero, Ellen Broad, Robert Burrell, Michael Carroll, Alberto Cerda, Ronan Deazley, Niva Elkin, Sean Flynn, Christophe Geiger, Michael Geist, Daniel Gervais, Rebecca Giblin, Lucie Guibault, Gwen Hinze, Bernt Hugenholtz, Meredith Jacob, Ariel Katz, Dick Kawooya, Howard Knopf, Kaya Koeklue, Oliver Metzger, Pedro Mizukami, Caroline Ncube, Sylvie Nerisson, Pedro Paranagua, Pranesh Prakash, Henning Ruse-Khan, Matt Sag, Pam Samuelson, Martin Senftleben, Jennifer Urban, Stef van Gompel, Fred Von Lohmann, and Peter Yu. Funding to support this research and the Global Expert Network on Copyright User Rights has been provided by the International Development Research Centre, Open Society Foundations, Ford Foundation, and through unrestricted gifts to the American University Program on Information Justice and Intellectual Property. All of the opinions and findings presented in this report are those of the Authors and were not directed or influenced by any of our funders.
} 
중 


\section{TABLE OF CONTENTS}

I. INTRODUCTION

2

II. UNTESTED HYPOTHESES ON THE IMPACT OF USER RIGHTS 4

A. INNOVATION AND GROWTH IN THE TECHNOLOGY SECTOR 5

B. CREATIVITY AND NEW WORKS 6

III. DEVELOPING THE USER RIGHTS DATABASE 8

A. MAPPING OPENNESS, FLEXIBILITY \& GENERALITY 8

B. OVER TIME 9

C. THROUGH AN EXPERT SURVEY 9

IV. RESULTS AND ANALYSIS I 3

A. TRENDS IN USER RIGHTS REFORM 13

1. The development gap 13

2. The Digital Gap 14

B. THE IMPACT OF OPEN USER RIGHTS 15

1. The Impact of Openness on the Technological Industry 15

2. The Impact of Openness on Traditional Copyright Industries

3. The Impact of Openness on Scholarship 19

V. CONCLUSION 22 

opyright law is the subject of increasingly contested debates around the world. Much of this reform is being driven by a perceived need to adapt outdated copyright laws to the digital age. Copyright owners often advocate that these reforms should center on expanding the length, scope, and enforceability of exclusive rights. However, there is a growing recognition that the digital environment warrants expansions in so-called user rights - rights to use copyrighted material without the permission of owners to facilitate a range of modern activities from social media to Internet search. ${ }^{1}$

Few empirical studies analyze the impact of different ways to expand user rights for the digital environment. One reason for the lack of empirical research on the impact of more open and flexible user rights has been the absence of a tool to measure changes in this variable of the law. To promote additional and enhanced research into the impact of user rights, we created the User Rights Database. The User Rights Database is an open access repository of coded data showing how and when copyright user rights have changed over time in a representative sample of different countries.

We have begun to use the User Rights Database in empirical research projects. The first insight we draw is that there is a general trend toward more open user rights over time in all of the countries. The growth is unequal, however. Developing countries in our sample are now at the level of openness that existed in the wealthy countries about thirty years ago.

Another insight from our data is that very few countries have sufficient user rights most needed to support creativity and innovation in the digital economy. Crucial digital exceptions include those permitting transformative and non-expressive uses, including for text- and data-mining. Countries with an open general exception, such as the U.S. fair use right, have been quickest to authorize these new uses. ${ }^{2}$

\section{$\ldots \ldots \ldots . . . . . . .0$}

${ }^{1}$ WIPO Copyright Treaty pmbl.(Dec. 20,1996) (describing as a principle objective to promote "balance" between protections for copyright owners and user rights that serve "the larger public interest, particularly education, research and access to information"); accord Beijing Treaty on Audiovisual Performances pmbl. (Jun. 24, 2012); US-Korea Free Trade Agreement art.18.4 n.11 ( June 30, 2007 ) ("For greater certainty, each Party may adopt or maintain limitations or exceptions to the rights described in paragraph 1 for fair use, as long as any such limitation or exception is confined as stated in the previous sentence"); S. Rep. No. 114-42 (2015) (instructing "that U.S. trade agreements should contain copyright provisions that...foster an appropriate balance in copyright systems, inter alia by means of limitations and exceptions").

${ }^{2}$ There are eight countries around the world that have a clause (whether called "fair use," "fair dealing," or something else) with the essential hallmarks of fair use. See Appendix II: Examples of Flexible Limitations and Exceptions from Existing and Proposed Laws, available at http://infojustice.org/flexible-use. 


\section{THERE IS A GROWING RECOGNITION THAT THE DIGITAL ENVIRONMENT WARRANTS EXPANSIONS IN SO-CALLED USER RIGHTS}

We used the database in a series of econometric tests. Our data supports the existing theoretical literature that suggests that more open user rights promote innovation and creativity. Namely, we find:

- More open user rights environments are associated with higher firm revenues in information industries, including software, and computer systems design.

- More open user rights environments are not associated with harm to industries known to rely upon copyright protection, such as publishing and entertainment.

- Researchers in countries with more open user rights environments produce more scholarly output and more high-quality output.

The rest of this paper describes our hypotheses, methodologies and results in more detail. Section II surveys the existing theoretical literature that suggests that more open user rights promote innovation and creativity. Section III describes the methodologies we used to construct the User Rights Database. Section IV reports the findings of our econometric analysis. 


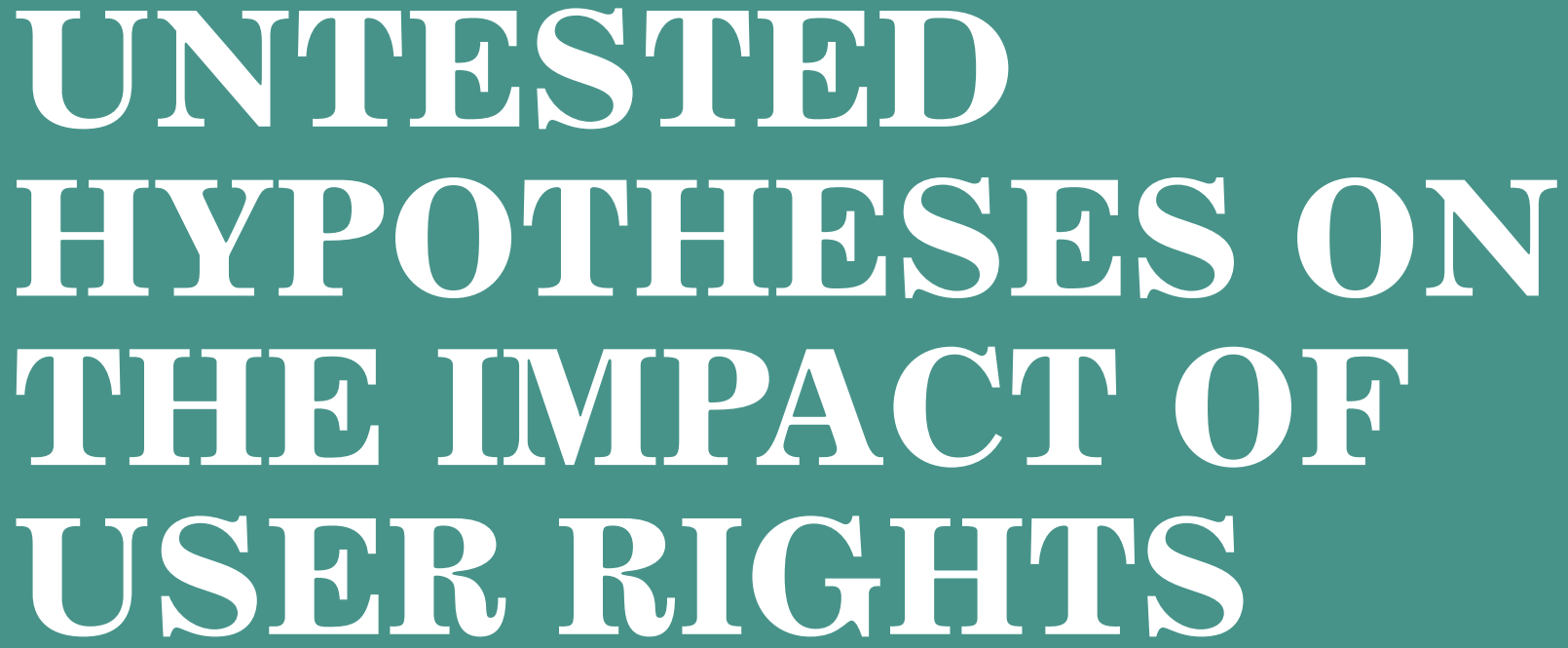

W do not know much about the impact of different ways to define copyright user rights. ${ }^{3}$ The early work in the field on the benefits of user rights to overcome market failure takes no position on the particular shape of user rights that may better serve even that limited purpose. ${ }^{4}$ The benefits of different formulations of user rights in copyright law may be diffuse, and therefore hard to measure. ${ }^{5}$ But at least two major hypotheses one frequently hears in copyright debates appeared to us as testable. It is often claimed that adopting U.S.-style "fair use" rights may drive innovation and growth in the technology sector. It is also frequently claimed may create larger stockpiles of inputs for creators, leading to more local production of works of creativity. Before explaining our methodologies for testing these claims, we review some of the most useful literature we found on these topics.

\begin{abstract}
${ }^{3}$ Most of the economic literature on the impact of copyright focuses on the degree to which digital piracy may harm legitimate sales of works, compare Rahul Telang \& Joel Waldfogel, Piracy and New Product Creation: A Bollywood Story (Nainz College Research Paper, 2014) (finding that high levels of piracy depress the production of new Bollywood films); with Joel Waldfogel, Bye, Bye Miss American Pie? The Supply of New Recorded Music Since Napster (NBER Working Paper No. 16882, 2011) (finding that increased file sharing through Napster led to no decrease in the creation of musical works), or on effects of copyright term extensions see Douglas Gomery, Research Report: The Economics of Term Extension for Motion Pictures (1993); see also Jeremy Reichman, The Duration of Copyright and the Limits of Cultural Policy. 14 Cardozo Arts \& Ent. L.J. 625-654 (1996); Raymond Shih Ray Ku et al., Does Copyright Law Promote Creativity? An Empirical Analysis of Copyright's Bounty, 62 Vand. L. Rev. 1669, 1671 (2009); Cecil C. Kuhne III, The Steadily Shrinking Public Domain: Inefficiencies of Existing Copyright Law in the Modern Technology Age, 50 Loy. L. Rev. 549 (2009); I.P.L. Png \& Qiu-hong Wang, Copyright Law and the Supply of Creative Work: Evidence from the Movies (2009). There are a handful of studies on the impact of copyright "strength." See Lee B. Becker \& Tudor Vlad, Copyright Consequences: Central European and U.S. Perspectives, 163-197 (Lee B. Becker \& Tudor Vlad eds., 2003) (finding that stronger copyright protection has been associated with the production of more print media). But there is little studying the converse.

${ }^{4}$ See Wendy Gordon, Fair Use as Market Failure: A Structural and Economic Analysis of the "Betamax" Case and Its Predecessors, 82 Colum. L. Rev. 1600 (1982) (describing that she uses the term "fair use" generically to refer to any authorization of free use of a work)/The market failure literature generally finds theoretical economic justifications for free use rights when (and perhaps only when) markets lack sufficient mechanisms for information sharing and transaction-free exchanges to enable licensing on a willing buyer-willing seller model. Permitting free uses in such a context produces net gains to social welfare - transactions occur for no loss to the copyright owner. Id., see also Dan Burk \& Julie Cohen, Fair Use Infrastructure for Rights Management Systems, 15 Harv. J.L. \& Tech. 41-83 (2001). A related stream of literature theorizes that even piracy can produce net social benefits where it does not displace actual sales. See Carlos Primo Braga \& Carsten Fink, Reforming Intellectual Property Rights Regimes: Challenges for Developing Countries, 1 J. Int'l Econ. L. 537-554 (1998). But the justifications for user rights is much broader than market failure, even if we focus on its economic aspects. See Mark A. Lemley, Property, Intellectual Property, and Free Riding, 83 Tex. L. Rev. 1031, 1076 (2005) (describing the fallacy of overprotecting rights to eliminate all "free riding" and calling for a focus instead on the ultimate utilitarian justification of the minimum scope of exclusive rights consistent with giving due reward to creators to incentivize production and innovation).
\end{abstract}




\section{a. Innovation and Growth in the Technology Sector}

Those who rely on fair use often claim it is better for innovative businesses. Google, for example, has frequently and publicly explained that a core reason it grew its business in California instead of the UK is that fair use is more conducive to innovative enterprise than fair dealing. Why?

Fair use and fair dealing look a lot alike. They are both general exceptions in the sense that they apply to multiple different uses and purposes in a single user right. There is no real difference in the law between a "use" versus a "dealing." Both broadly cover any potential use/dealing with a work that may be covered by a copyright protection (e.g. reproduction, display, communication, etc.). The main difference is that the UK right operates on a closed list of purposes. To be a fair dealing in the UK statute, one must be using the work ONLY for the purposes of non-commercial research or study, criticism or review, or for the reporting of current events. The problem with list for innovators is that it does not include many modern purposes for which works are frequently - and fairly - used, such as for indexing the Internet, reverse engineering software to create interoperable products, or mining content for meta-data to create translation and other tools. Fair use is preferred because its list of permitted purposes is open.

This theme - that the openness of fair use is helpful for innovation and modern technology industries - appears in the literature. The basic idea is that laws that permit a larger scope for new technologies to use works in new ways, without previous approval by the legislature, creates a kind of store of resources promoting investments in technological innovation. ${ }^{6}$ A related literature describes the massive investments in the US economy from these so-called "fair use industries."

For the most part, this literature is theoretical rather than empirical. The fair use industry studies do not actually claim that changes in fair use will necessarily alter the fair use industries in any way. The implication is made but not proven. The empirical studies that have been done are limited to before/after policy change studies in single countries and over a comparatively short period of time. ${ }^{8}$ Most of this literature also supports, but does not actually seek to test, that it is the openness of fair use that leads to the benefits they find.

\footnotetext{
$\ldots \ldots \ldots$

${ }^{6}$ Fred von Lohmann, Fair Use as Innovation Policy, 23 Berkeley Tech. L.J. 8 (2008) (describing "fair use" rights, by which he means generally any private copying rights, as providing a "reservoir of incentive" to the development of private copying technology industries form theVCR to the I-Pod); see also Michael Palmedo, R\&D Spending and Patenting in the Technology Hardware Sector in Nations With and Without Fair Use (PIJIP Research Paper Series, Paper No. 02, 2017) (finding that technology hardware firms in countries with fair use spent more on research and development and received more patents); Joshua Lerner, The Impact of Copyright Policy Changes on Venture Capital Investment in Cloud Computing Companies, CCIA (2014) (demonstrating how a court ruling clarifying copyright user rights increased venture capital funding to American cloud technology firms); Michael A. Carrier, Copyright and Innovation: The Untold Story, 891 Wis. L. Rev. (2012) (focusing on the strength of copyright enforcement rather than exceptions, finding that aggressive online enforcement deterred venture capital funding for new technologies related to online music sharing).

${ }^{7}$ Andrew Szamosszegi \& Mary Ann McCleary, Fair Use in the U.S. Economy, CCIA (2017) (employing WIPO's methodology for the study of copyright industries to those that rely on copyright exceptions, in the U.S., finding that they employ 18 million workers and accounted for $16 \%$ of the U.S. economy).

${ }^{8}$ See Roya Ghafele \&Brooke Friedman, .4 footnote 11,exptions for Libraries and Archives, Benjamin Gilbert, A Counterfactual Impact Analysis of Fair Use Policy on Copyright Related Industries in Singapore (2014) (finding that technology hardware firms in Singapore enjoyed faster growth after the nation's introduction of fair use in 2006); Lerner (finding that clarification of fair use of remote DVR providers led to an explosion of investment into twhat is now the cloud storage industry); Barbara Biasi \& Petra Moser, Effects of Copyright on Science: Evidence from the WWII Book Replication Program (2016) (using a natural experiment to test the relationship between unfettered access to science knowledge and research output; the U.S.'s suspension of copyright on German science publications during World War II drove subsequent innovations that can be found in patent citations to these German works).
} 


\section{b. Creativity and New Works}

Another major argument in favor of fair use like provisions is that they promote more and better works of creativity. It has been posited, for example, that scholars and firms engaged in research will produce more in countries that allow greater rights to use published works. ${ }^{9}$ Others explain how greater user rights may contribute to the quality or value of creative output. ${ }^{10}$ Little of this literature zeros in, however, on the particular attributes of user rights that may be better or worse at promoting the ends they identify.

Empirical studies are also relatively limited. Studies have shown that more text and data mining research is published from countries that have adopted rights to use works for these purposes. ${ }^{11}$ Extensive survey evidence has shown that knowledge of fair use rights among US filmmakers leads to higher production values of their films; ${ }^{12}$ and correlatively that lack of knowledge of user rights in South Africa has depressed production values. ${ }^{13}$ But as with the work on innovation and the technology industry, cross-country, multiperiod studies on the impact of particular definitions of copyright user rights are lacking. ${ }^{14}$ ${ }^{9}$ Andrew Gowers, Gowers Review of Intellectual Property, HMSO (2006) (asserting that stronger research exceptions "create greater scope for
research on protected material by universities and business and expand the stock of knowledge"); see also Joanna Adcock \& Edward Fottrell,
The North-South Information Highway: Case Studies of Publication Access Among Health Researchers in Resource-Poor Countries, Global
Health Action (2008) (surveying health researchers from nine low income countries, finding that poor access to current literature in their
fields lessened their published output); Ana Langer et al., Why Is Research from Developing Countries Underrepresented in International
Health Literature, and What Can Be Done About It? 82 Bull. World Health Organ. 797-803 (2004) (highlighting limited access to published
literature as a barrier to further research into diseases prevalent in poor countries); Barbara Biasi \& Petra Moser, Effects of Copyright on
Science: Evidence from the WWII Book Replication Program (2016) (using a natural experiment to test the relationship between unfettered
access to science knowledge and research output; the U.S.'s suspension of copyright on German science publications during World War II
drove subsequent innovations that can be found in patent citations to these German works).

${ }^{10}$ Christophe Geiger, Promoting Creativity through Copyright Limitations: Reflections on the Concept of Exclusivity in Copyright Law, 12 Van. J. Ent. \& Tech. L. 515 (2010) (arguing that broader rights to use copyrighted materials may lead to higher production values in creative communities); Matthew J. Baker \& Brendan M. Cunningham, Court Decisions and Equity Markets: Estimating the Value of Copyright Protection, 49 J.L. \& Econ. 567, 567-596 (2006) (testing the effect of court cases on the value of copyright works); Yauhiro Arai \& Shinya Kinukawa, Copyright Infringement as User Innovation, 38 J. Cult. Econ. 131-144 (2014) (studying Japanese Dojinshi and finding value created by these derivative works. It is notable that in Arai and Kinukawa's model, producers of originals can maximize their welfare by ignoring Dojinshi even if transactions costs fall).

${ }^{11}$ Christian Handke et al., Is Europe Falling Behind in Data Mining? Copyright's Impact on Data Mining in Academic Research, 1-22 (2015), available at https://papers.ssrn.com/sol3/papers.cfm?abstract_id=2608513; see also Sergey Filippov, Mapping Text and Data Mining in Academic and Research Communities in Europe, The Lisbon Council (2014); Ian Hargreaves et al., Report from the Expert Group on Standardisation in the Area of Innovation and Technological Development, Notably in the Field of Text and Data Mining, European Commission (2014) (these papers find that countries with copyright exceptions allowing datamining without the consent of rightholders produce more research that use these techniques). See also Jerome Reichman \& Ruth Okediji, When Copyright Law and Science Collide: Empowering Digitally Integrated Research Methods on a Global Scale, 96 Minn. L. Rev. 1363, 1365-66 (2012) (justifying the need for extraction and reuse of pertinent scientific data); Ian Hargreaves, Digital Opportunity: A Review of Intellectual Property and Growth (2011) (illustrating the importance of text and data mining exceptions specifically to medical professionals).

${ }^{12}$ Patricia Aufderheide \& Peter Jaszi, Reclaiming Fair Use: How to Put Balance Back in Copyright, University of Chicago Press (2018) (recounting examples where knowledge and use of fair use by filmmakers led to increased value productions).

${ }^{13}$ Sean Flynn and Peter Jaszi. Untold Stories in South Africa: Creative Consequences of the Rights Clearance Culture for Documentary Filmmakers, White Paper (2010)

${ }^{14}$ National Research Council, Copyright in the Digital Era: Building Evidence for Policy, The National Academies Press (2013), available at https://doi.org/10.17226/14686. For an example of the kind of work that is lacking in the area of user rights, see Walter G. Park, The Copyright Dilemma: Copyright Systems, Innovation and Economic Development, 64 J. Int'l Aff. 1, 64 (2010). 
Table 1: Summary of Previous Literature

\begin{tabular}{|c|c|c|}
\hline Theme & Author & Hypothesis \\
\hline \multirow{6}{*}{$\begin{array}{l}\text { Investment, } \\
\text { innovation \& } \\
\text { technology firm } \\
\text { performance }\end{array}$} & Von Lohmann & Fair use leads to greater innovation - non-empirical \\
\hline & Palmedo & Fair use leads to more $R \& D$ spending $\&$ patents in tech hardware \\
\hline & Lerner & Clarification of user right led to more venture capital in cloud sector \\
\hline & Carrier & Aggressive copyright enforcement depressed innovative investments \\
\hline & Biasi and Moser & Access to more works led to more innovations drawing on them \\
\hline & Ghafele and Gilbert & Fair use led to positive outcomes in Singapore \\
\hline \multirow{10}{*}{$\begin{array}{l}\text { Creativity and } \\
\text { new works }\end{array}$} & Aufderheide and Jaszi & Utilizing fair use raises film production values \\
\hline & Geiger & More robust copyright exceptions lead to more creative works \\
\hline & Aria Kinukawa & Greater openness in copyright leads to more creative works \\
\hline & Handke, Guibault, Vallbé & Copyright limitations for text- and datamining shape research output \\
\hline & Filippov & Copyright limitations for text- and datamining shape research output \\
\hline & Hargreaves 2014 & Copyright limitations for text- and datamining shape research output \\
\hline & Hargreaves 2011 & Copyright limitations for text- and datamining shape research output \\
\hline & Reichman \& Okediji & Researchers need better access to research and data \\
\hline & Adcock and Fottrell & Lack of access to copyrighted journals hinders medical research \\
\hline & Langer et al & Lack of access to copyrighted journals hinders medical research \\
\hline
\end{tabular}



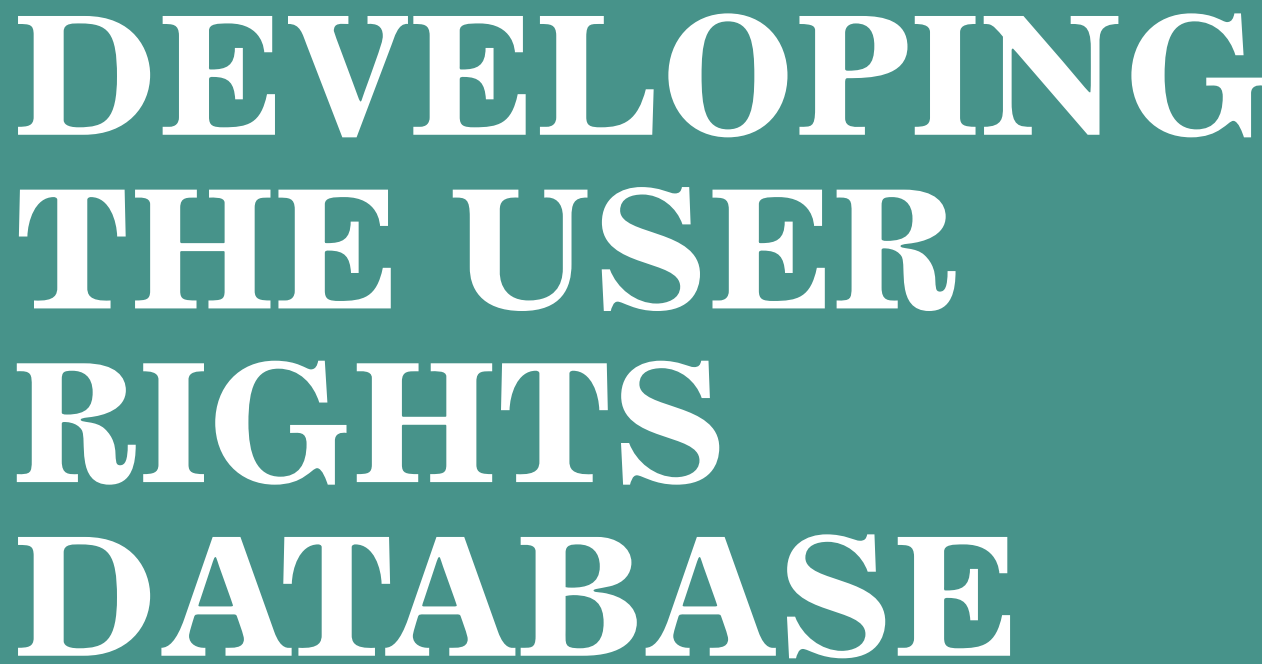

W e set out to promote more and better empirical research on the value of user rights. Our first step in this process was to convene a group of leading copyright economists and researchers to discuss ways to improve the state of the field.${ }^{15}$ One problem stood out - we frequently heard that there was no existing database capturing changes in laws over time that one could use as an independent variable in empirical projects. Thus was born our drive to create the User Rights Database.

\section{a. Mapping Openness, Flexibility \& Generality}

We began our research by identifying countries with and without "fair use" rights modeled on Section 107 of the U.S. Copyright Act. But we quickly observed that terminology alone could not define who did and did not have a "fair use" right. As Band shows, for example, some "fair dealing" rights, e.g. Singapore, are open to use for any purpose, and thus operate more like the US fair use right than UK fair dealing. ${ }^{16}$ But openness to purpose is not unique to fair use rights. South Africa's quotation right permits the quoting of any work, in any other work, for any purpose, subject to compliance with "fair practice."

The project collected and analyzed a large number of copyright laws from around the world. ${ }^{17}$ We found that many - indeed most - have one or more exceptions with at least one of the following elements often associated with fair use:

- Openness: the user right can be applied to an open, as opposed to a defined (aka closed), list of purposes, uses, works or users;

- Flexibility: the user right is applied through a flexible proportionality test that balances the interests of the rights holder with those of the user and general public;

- Generality: the exception promotes uniform application by applying a single test to a group of uses or purposes.

$\ldots \ldots \ldots$

${ }^{15}$ Information regarding the meeting on the Law and Economics of Copyright User Rights held on September 26,2013 is available at http:// www.pijip.org/events/law-and-economics-of-copyright-users-rights/.

${ }^{16}$ Jonathan Band, The Fair Use/Fair Dealing Handbook (2015).

${ }^{17}$ See Masterlist: Limitations and Exceptions Provisions in National Laws, http://infojustice.org/flexible-use. The project also reviewed past studies and convened legal and economic members of the Global Expert Network on Copyright User Rights in several workshops to discuss research methodologies. 
Using this terminology, we can distinguish between different operative elements of user rights without relying on their own terminology. The U.S. fair use right in Section 107 is open (in each dimension), flexible, and general. The UK fair dealing clause is a flexible, general exception - but it is not open to any purpose. The South African quotation right is open to any purpose and is flexible, but is not open to any kind of use and is not general.

\section{b. Over Time}

There are a small number of useful resources that distinguish elements in the design of user rights. There are extensive studies of differences in the formulations of common law (aka "fair use" and "fair dealing") and civil law "closed list" exception systems. ${ }^{18}$ Others have catalogued fine differences between the wording of laws within "fair use" and "fair dealing" countries - interestingly reporting the lack of difference between the two categories. ${ }^{19}$ None of these resources provide the grist for the mill of independent variables, however, because none tracks changes in the elements they describe over time. To enable a range of empirical - especially econometric - methodologies, we need to know not only how policy contexts differ between countries now, but also how (and when) they have changed.

\section{c. Through an Expert Survey}

We have been part of the building, since 2011, of the Global Expert Network on Copyright User Rights, a group of experts from around the world doing research and providing technical assistance on the value of user rights to society. ${ }^{20}$ Our research program at American University is also an affiliate of the Creative Commons Affiliate Network, which has a "legal lead" in scores of countries around the world. From these networks we sought individuals willing and able to chart the history of openness in their copyright laws with us. ${ }^{21}$

We identified twenty categories of user rights common in many copyright systems, listed below.

\section{Limitations and Exceptions}

\begin{tabular}{llll} 
General exception & Computer Programs & Transformative Use & National Government Works \\
\hline Quotation & $\begin{array}{l}\text { Databases or Other Compilations } \\
\text { of Non-Original Facts }\end{array}$ & Parody and/or Satire & Exhaustion of Rights \\
\hline Education & Text and Datamining & Incident Inclusion & $\begin{array}{l}\text { Safeguards from Secondary/ } \\
\text { ISP Liability }\end{array}$ \\
\hline Research & Library Rights & Panorama Right & Temporary Copies for \\
& & Technological Processes \\
\hline $\begin{array}{l}\text { Personal or Private } \\
\text { Users }\end{array}$ & Disability Access & Orphan Works & Supremacy of Contracts
\end{tabular}

$\ldots \ldots \ldots$

${ }^{18}$ See e.g. Max Planck Institute for Innovation and Competition; World Intellectual Property Organization (WIPO), Standing Comm. on Copyright and Related Rights(SCCR), Study on Copyright Limitations and Exceptions for Libraries and Archives, SCCR/30/3 (June 10, 2015); ; WIPO, SCCR, Draft Study on Copyright Limitations and Exceptions for Educational Activities, SCCR/32/4 (May 9, 2016); World Intellectual Property Organization (WIPO), Standing Comm. on Copyright and Related Rights (SCCR), Updated Report on the Questionnaire on Limitations and Exceptions, SCCR/21/7 (Oct. 2, 2010).

${ }^{19}$ Jonathan Band, The Fair Use/Fair Dealing Handbook (2015) (reporting, e.g., that the "fair use" general exception in Uganda is not open to application to a use for any purpose, but the "fair dealing" general exception in Singapore is).

${ }^{20}$ The names of the founding network members are identified at http://infojustice.org/flexible-use Currently the Network is much larger including over 80 individuals from over 50 countries.

${ }^{21}$ The names of the respondents and their completed surveys are available at http://infojustice.org/survey. 
We chose the period 1970-2016 to capture the modern period in copyright law reform, coinciding with the introduction of technologies like the photocopy machine and videocassette recorder through the present.

For each user right, we surveyed experts from our networks on when their law permitted various dimensions of openness (e.g. to works, purposes and users), as well as whether the exception has a flexible balancing test. An example of one page of the survey is included below. In total, it collects over 120 inputs about the construction of user rights in each country over time, providing a rich source for measuring change. ${ }^{22}$

\section{General Exception}

Instructions:

Column (1) Enter the ranges of years since 1970, if any, when the law included a general exception for the use of copyrighted works

Column (2-6) Enter the ranges of years since 1970, if any, when the characteristics listed in the column headers applied to the general exception

Column (7) Provide citations to the law (including legislated law, regulations, and court cases) that support your answers

\begin{tabular}{|c|c|c|c|c|c|c|c|}
\hline & $\begin{array}{l}\text { (1) Exeption } \\
\text { recognised }\end{array}$ & $\begin{array}{l}\text { (2) Open to } \\
\text { any purpose }\end{array}$ & $\begin{array}{l}\text { (3) Open to } \\
\text { commercial } \\
\text { uses }\end{array}$ & $\begin{array}{l}\text { (4) Open to use } \\
\text { of any type of } \\
\text { work }\end{array}$ & $\begin{array}{l}\text { (5) Open to any } \\
\text { type of user }\end{array}$ & $\begin{array}{l}\text { (6) Subject to a } \\
\text { balancing test }\end{array}$ & (7) Citations \\
\hline $\begin{array}{l}\text { Clearly } \\
\text { included }\end{array}$ & & & & & & & \\
\hline $\begin{array}{l}\text { Mostly/ } \\
\text { probably } \\
\text { included }\end{array}$ & & & & & & & \\
\hline $\begin{array}{l}\text { Mostly/ } \\
\text { probably not } \\
\text { included }\end{array}$ & & & & & & & \\
\hline Not included & & & & & & & \\
\hline
\end{tabular}

(8) Comments

We wanted to capture all relevant changes in the law, whether or not they were included in the statute itself. ${ }^{23}$ We also wanted to identify user rights whether they occurred in a "limitation," "exception," definition of the scope of protection, or elsewhere. We therefore instructed our respondents to define both "law" and "user rights" "broadly to document the full range of legal permission to use copyright material without authorization that exist in all facets of law." ${ }^{24}$

\footnotetext{
${ }^{22}$ The instrument is available at http://infojustice.org/survey

${ }^{23}$ In many countries, judicial or administrative rulings may change the openness of user rights. Canada is a place where this has happened recently. See Michael Geist, The Copyright Pentalogy: How the Supreme Court of Canada Shook the Foundations of Canadian Copyright Law (2013)

${ }^{24}$ We used the following definitions:

"Law" is meant to include all authoritative, published rules or interpretations. Such law may include statutory law, administrative regulations or directives, decisions by courts, enforcement agencies, or others.

"User rights" is defined as any functional permission to use copyright protected material without authorization of the right holder. User rights may exist in any part of the law, including in limitations or exceptions to protection, in definitions of the scope of protection or of copyrightable subject matter, in automatic remuneration schemes (a.k.a. liability rules or statutory licenses), and in protections from liability or enforcement. User rights may exist within copyright specific statutes or decisions, or by virtue of other areas of law, such as constitutional rights, competition, consumer protection, or other fields of law.
} 
We wanted to capture the fact that "changes in the law often occur through periods of re-interpretation in which there may be periods of ambiguity." ${ }^{25}$ This is particularly, but not only, the case in common law countries. ${ }^{26}$ We therefore asked respondents for their "judgment on the degree of clarity in the law in regard to each user right" on a four point spectrum between "not included" and "clearly included."

The database is composed of 21 countries from different regions, legal systems, and development levels. ${ }^{27}$ Roughly half of the countries in the data set are middle or low income countries.

\section{Country Responses}

$\begin{array}{lr}\text { Australia } & \text { Argentina } \\ \text { Finle } & \text { Botswana } \\ \text { Japan } & \text { Brazil } \\ \text { Korea } & \text { China } \\ \text { Netherlands } & \text { Colombia } \\ \text { Portugal } & \text { India } \\ \text { Singapore } & \text { Peru } \\ \text { Slovakia } & \text { South Africa } \\ \text { Switzerland } & \text { Ukraine } \\ \text { United States } & \text { Vietnam } \\ & \end{array}$

${ }^{25}$ PIJIP, Copyright User Rights Survey 1, 2 (2016) available at http://infojustice.org/survey.

${ }^{26}$ Although there may be formal distinctions in the treatment of judicial precedent between civil and common law countries, all of our civil law experts opined that judicial action can and does change the effective operation of the law in civil law countries. In Brazil, for example, a series of judicial decisions has had the effect of recognizing an open, flexible, and general exception even without statutory change or a formal system requiring the following of judicial precedent. See survey response of Allan Rocha de Souza from Brazil, available at http:// infojustice.org/survey.

${ }^{27}$ The experts who contributed to the study include: Beatriz Busaniche, Argentina; Kimberlee Weatherall, Australia; Enyinna S. Nwauhce, Botswana; Allan Rocha de Souza, Brazil; J. Carlos Lara, Chile; Hong Xue, China; Marcela Palacio-Puerta, Columbia; Taina Pihlajarinne \& Anette Alén-Savikko, Finland; Shamnad Basheer \& Pankhuri Agarwal, India; Tatsuhiro Ueno \& Ayuko Hashimoto, Japan; Heesob Nam, Korea; Marco Caspers, Netherlands; Miguel Morachimo, Peru; Teresa Nobre, Portugal; Daniel Seng \& David Tan, Singapore; Zuzana Adamová, Slovak Republic; Caroline Ncube, South Africa; Simon Schlauri, Switzerland; Maksym Naumko \& Andriy Bichuk, Ukraine; Rami Olwan, United Arab Emirates; Peter Jaszi, United States; Nhan T.T. Dinh, Vietman. The study and responses are available at http://infojustice. org/survey. 
THE USER RIGHTS DATABASE

After receiving each completed survey, we reviewed them and corresponded with authors to clarify answers. We had law student researchers cite-check each response. Completed surveys were then coded. We gave a score of 0 where a law did not have a particular element up to a 3 if the law "clearly" had the element. ${ }^{28} \mathrm{The}$ final survey responses are posted online, in both original and coded form. ${ }^{29}$

The outcome is the User Rights Database. It is the only compilation of information on change in the fine details of copyright user rights over time in a broad set of representative economies around the world. 


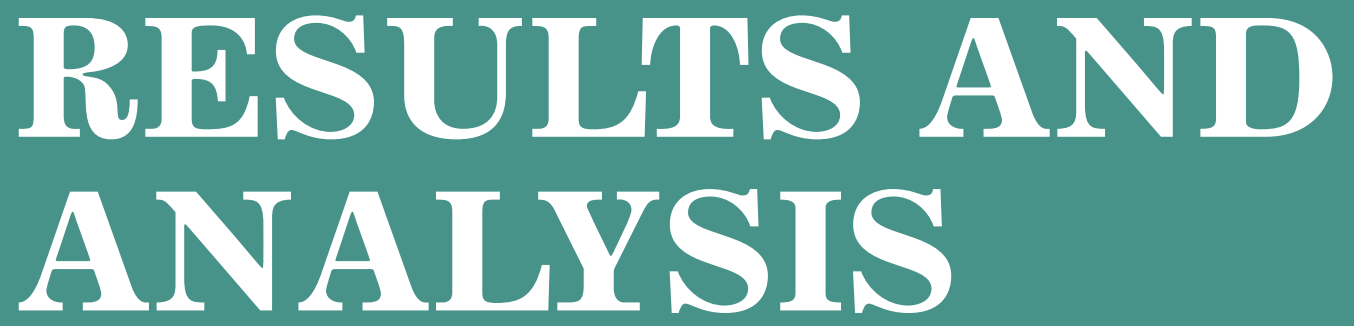

aving constructed the database, we set out to test the impact of user rights on firm performance in technology industries and the creation of new works.

\section{Our findings include that:}

- There is a general trend toward more open user rights over time in all of the countries, but developing countries in our sample are about 30 years behind on average.
- More open user rights environments are associated with higher firm revenues in information industries, including software, and computer systems design; but are not associated with harm to copyright intensive industries.
- Researchers in countries with more open user rights environments produce more scholarly output and more highquality output.

\section{a. Trends in User Rights Reform}

\section{The Development Gap}

In our sample, all of the countries have moved toward more open user rights over time. The shift toward adopting "fair use"- style general exceptions that are fully open, general and flexible is just one trend..$^{30}$ Even where countries focus on specific exceptions, such as for education, there is a trend toward exceptions that are open to different works, uses and purposes. All of our laws, in this sense, are becoming more open. But we are not all becoming more open at an equal pace.

Figure 1 reports the average scores of two subsets of respondent countries - the 11 high-income and 10 middleincome countries in our set. A value of 3.0 would indicate that every user right is fully open to all works, uses, and users. On average, there is a clear upward (toward more open) trend for both the high- and middle-income subsets, indicating a greater opening of user rights provisions across the board.

The high-income countries in our study have more open user rights in their laws, and the gap between them and developing countries has been growing since the early 1990s. As one participant from a developing country at a workshop of ours remarked on seeing the data, "we [developing countries] are 30 years behind!"

\footnotetext{
$\ldots \ldots \ldots$

${ }^{30}$ For a recent discussion of this trend, see Peter Yu, Customizing Fair Use Transplants

${ }^{\text {Texas }}$ A\&M University School of Law Legal Studies Research Paper No. 17-78
} 
Figure 1: Growth of Openness, 1970 - Present

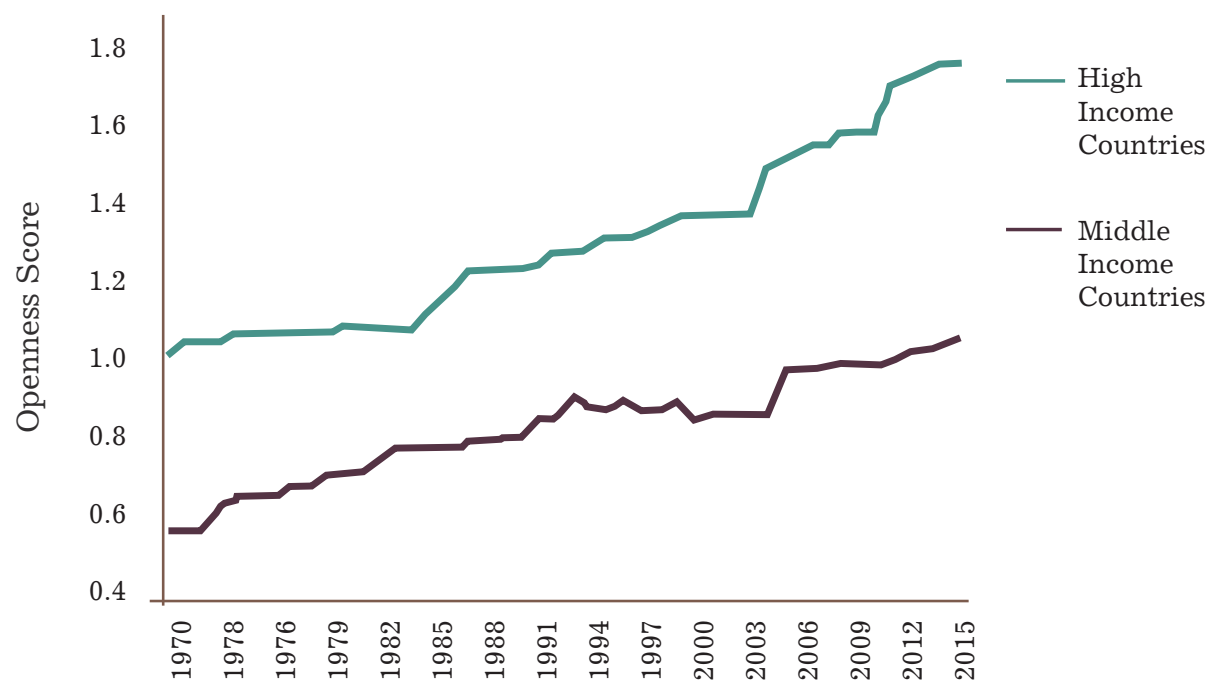

\section{The Digital Gap}

It is commonly posited by policy makers and advocates that it is the digital environment that is demanding change. One might therefore hope to see in the data a trend toward adoption of some of the categories of user rights that are most enabling of digital technology and Internet culture. We searched for trends toward adopting new digital rights, including rights to transformative uses - uses that transform material into totally new works, like a mash-up - and to use works for "non-expressive" purposes, such as for text and data mining. ${ }^{31}$ But adoption of such rights is rare, and is concentrated in the countries with open general exceptions.

Figure 2a: Disaggregated Change in Middle Income Countries

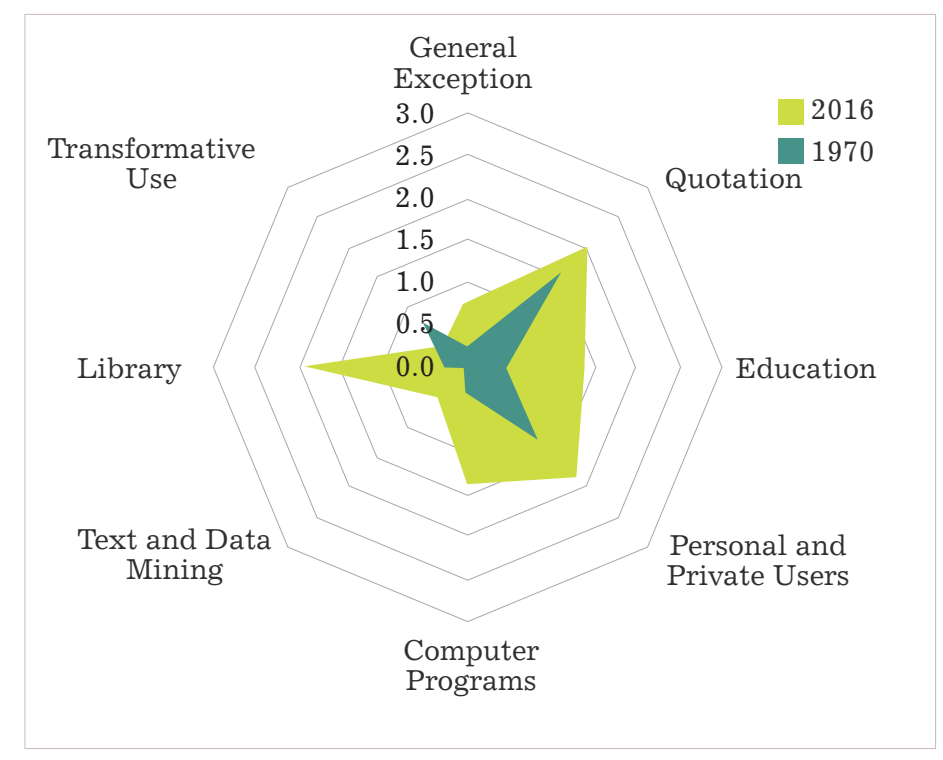


Figure 2b: Disaggregated Change in High Income Countries

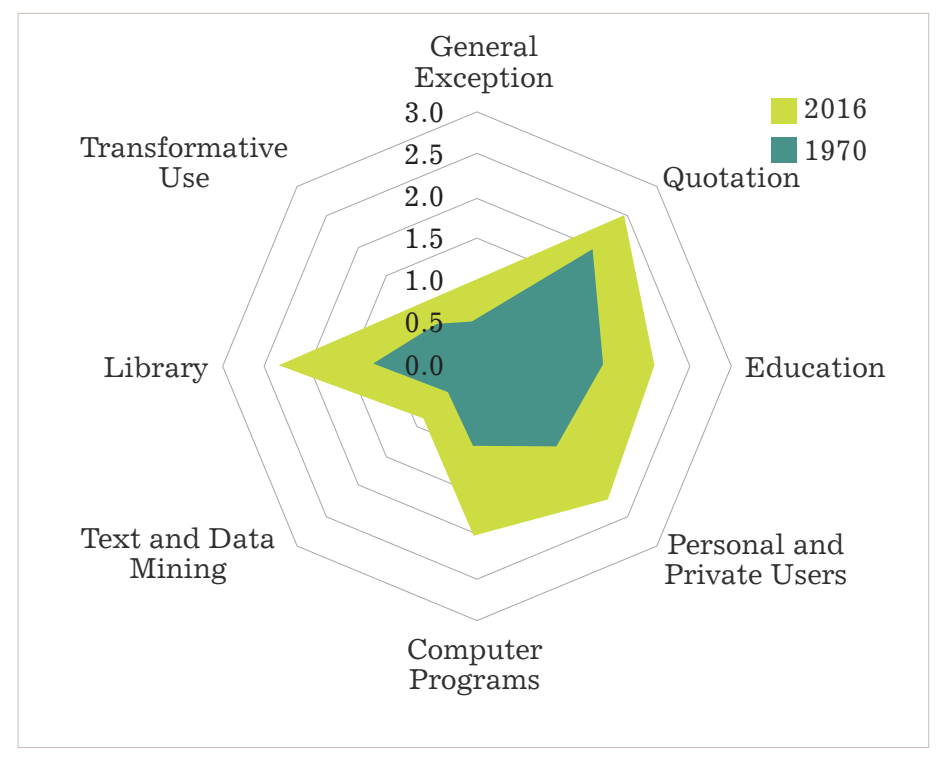

Figures 2(a) and 2(b) show the average openness in eight subsections of the overall openness score. The origin of each is zero. The center of the radar graph thus represents an openness score of zero for each area of user rights. The maximum value for each is three, which would indicate that a particular limitation is fully open to any user, any type of work, and for any purpose. Figure 2(a) shows the average from the middle-income countries in our sample, and figure $2(\mathrm{~b})$ shows the average for the high-income countries. In each, the darker area represents the scores from 1970 and the lighter represents them from 2016. Few countries, and almost no developing countries, have sufficient user rights most needed to support the digital economy, including for transformative use or text- and datamining, or a general exception that can adapt to new technologies.

\section{b. The Impact of Open User Rights}

Having established trends in the data on the degree to which countries are adopting more open user rights, we set out to test our two major hypotheses about potential effects - that user rights may promote technology industry growth, and that they may promote more and higher quality creative output. We find positive results in both regards, without evidence of harm to traditional copyright industries. 


\section{The Impact of Openness on the Technological Industry}

\section{a. Domestic Technology Industry}

We collected firm-level data from Thomson Reuters for companies in select industries based in the countries represented in our Copyright User Rights Database, other than the United States (which is an upper-bound outlier). The industries selected were the software, computer systems design, and scientific R\&D industries, identified by North American Industry Codes 5112, 5415, and 5417. The correlation between the openness score and logged ${ }^{32}$ revenue per employee is visually represented (without controls) in Figure $3 .^{33}$

Figure 3: Openness Score and Revenue per Employee

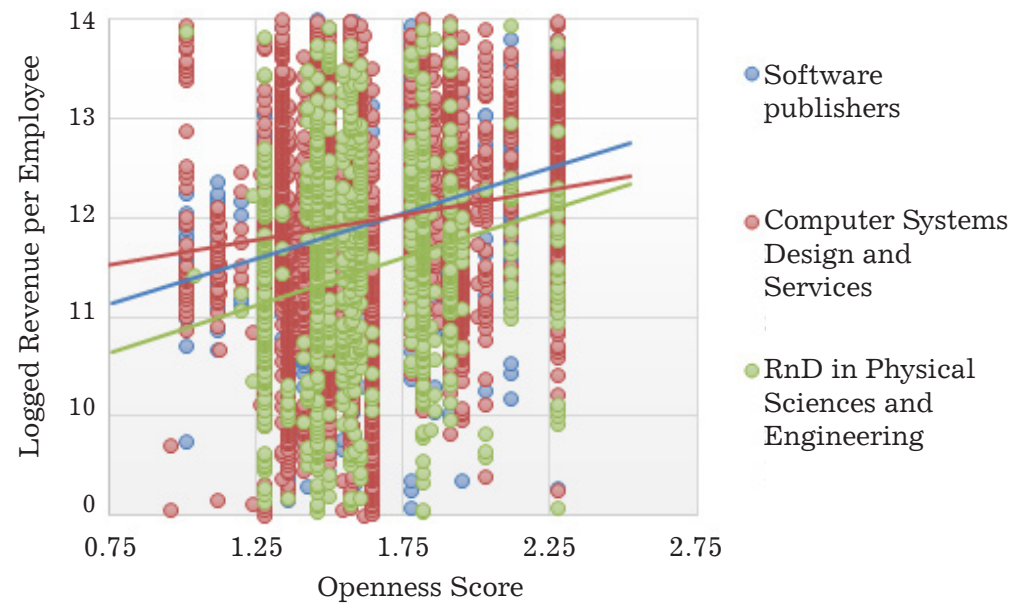

We next ran separate regressions for each industry to test the general correlation with controls for other major factors that could account for the differences observed. The number of each firm's full-time employees is used to control for firm size. We used World Bank data on GDP per capita and population to control for country wealth and size, respectively, and used fixed effects to control for time. Table 2 presents the results.

As shown in Table 2, our openness score has a positive and highly statistically significant relationship with total revenue in all three industries, controlled for other factors. A one-unit increase in the openness score is associated with an increase in revenues of 50\%-70\%, even while holding firm size, country wealth, and country size constant, and controlling for time. ${ }^{34}$

\footnotetext{
${ }^{32}$ Economists usually take the natural logarithm of skewed datasets to perform econometric analysis. Technically, a natural logarithm is the logarithm to base $e(=2.718 \ldots)$, meaning it is the value $x$ to which the constant $e$ must be raised in order to equal the original value of the observation. In practical terms, natural logarithms convert skewed datasets into datasets approximating a normal distribution, allowing for econometric analysis. They also change interpretation of the coefficients in regression analyses to indicate percent changes rather than unit changes of the original data.

${ }^{33}$ Note that a one-unit increase in our openness score is a very substantial increase in the actual openness of limitations in a country's copyright law, since our Openness Score runs from 0 to 3.

${ }^{34}$ The overall model describes the variation in the data quite well. The size of the firm has the strongest association with the size of revenues, as expected. Software publishers and computer system design firms have higher revenues when they are operated in wealthier countries, though the relationship between revenues and wealth is insignificant for the R\&D firms. The R-squared for each of the industries is 0.72 or better, indicating a good overall fit. An R-squared is the most commonly used measurement of the quality of a full regression model. It measures the percentage of the variance around a fitted regression line that is jointly explained by all of the covariates. We have also run the same regressions using net income instead of total revenue, finding a positive, significant relationship between this variable and openness for firms in the software publishing and computer system design industries. However, there is no longer a positive, significant relationship for science R\&D firms. There is less data available for net income than total revenue, especially for the R\&D firms, which may influence these results. Still, the findings generally support the overall finding that openness in copyright limitations is associated with positive outcomes for firms in industries relying upon copyright limitations.
} 
TABLE 2: Firms in Industries that Rely on Copyright Limitations Dependent Variable: (Logged) Total Revenue

(1)

(3)

\begin{tabular}{|c|c|c|c|}
\hline VARIABLES & $\begin{array}{l}\text { Software } \\
\text { Publishers }\end{array}$ & $\begin{array}{l}\text { Computer Systems Design } \\
\text { and Related Services }\end{array}$ & $\begin{array}{l}\text { R\&D in the Physical } \\
\text { Engineering and Life } \\
\text { Sciences }\end{array}$ \\
\hline \multirow[t]{2}{*}{ Openness } & $0.501 * * *$ & $0.652 * * *$ & $0.696^{* * *}$ \\
\hline & $(0.0861)$ & $(0.0802)$ & $(0.246)$ \\
\hline \multirow[t]{2}{*}{ (Log) Employment } & $0.945 * * *$ & $0.912 * * *$ & $1.143 * * *$ \\
\hline & $(0.0181)$ & $(0.00820)$ & $(0.0285)$ \\
\hline \multirow[t]{2}{*}{ GDP per capita } & $1.49 \mathrm{e}-05^{* * *}$ & $1.58 \mathrm{e}-05^{* * *}$ & $2.68 \mathrm{e}-06$ \\
\hline & $(1.73 \mathrm{e}-06)$ & $(1.49 \mathrm{e}-06)$ & $(3.69 \mathrm{e}-06)$ \\
\hline \multirow[t]{2}{*}{ Population } & $-4.47 \mathrm{e}-10 * * *$ & $-1.82 \mathrm{e}-10 * * *$ & $-4.73 \mathrm{e}-10 * *$ \\
\hline & $(6.08 \mathrm{e}-11)$ & $(5.60 \mathrm{e}-11)$ & $(2.00 \mathrm{e}-10)$ \\
\hline \multirow[t]{2}{*}{ Constant } & $11.05 * * *$ & $11.05^{* * *}$ & $9.670 * * *$ \\
\hline & $(0.189)$ & $(0.168)$ & $(0.497)$ \\
\hline Observations & 2,643 & 6,455 & 999 \\
\hline R-squared & 0.742 & 0.780 & 0.714 \\
\hline Time FE & Yes & Yes & Yes \\
\hline
\end{tabular}

Robust standard errors in parentheses

$$
* * * \mathrm{p}<0.01, * * \mathrm{p}<0.05, * \mathrm{p}<0.1
$$

\section{Impact of Openness on Returns to Foreign Affiliates of Multinationals}

Next, we tested the effect of copyright openness on returns to firms receiving foreign direct investment from the United States. This study was in part to provide a proxy for testing the trade impacts of copyright balance, a topic to which we plan to return. We found a positive relationship between openness in copyright user rights and returns to firms that partner with U.S.-based Multinationals.

This set of tests used industry-level data on foreign affiliates of American Multinational Enterprises, taken from the Bureau of Economic Analysis. ${ }^{35}$ We collected data on three variables of interest: net income, total sales, and value added for affiliates in the Scientific and Technical Services sector between 1999 and 2014. These are the industries under the two-digit NAICS code 54, which include research and development services and computer systems development, among others. ${ }^{36}$

\footnotetext{
$\ldots \ldots \ldots$

${ }^{35}$ The data is available at the two-digit North American Industry Classification System (NAICS) level of disaggregation. The BEA tables are available at https://www.bea.gov/international/di1usdop.htm.

${ }^{36}$ NAICS identifies industries at different levels of disaggregation, which are indicated by the number of digits. Two-digit classifications are very broad (i.e. - NAICS 54: "Professional, scientific, and technical services"), and more precise classifications are nested underneath and indicated by more digits (i.e. - NAICS 5415: "Computer systems design and related services"). For data on the activities of foreign subsidiaries of U.S. MNEs, the Bureau of Economic Analysis only provides data at the two-digit level of disaggregation.
} 
Figure 4: Openness Score and Performance of Firms Receiving Investment by U.S. Multinationals

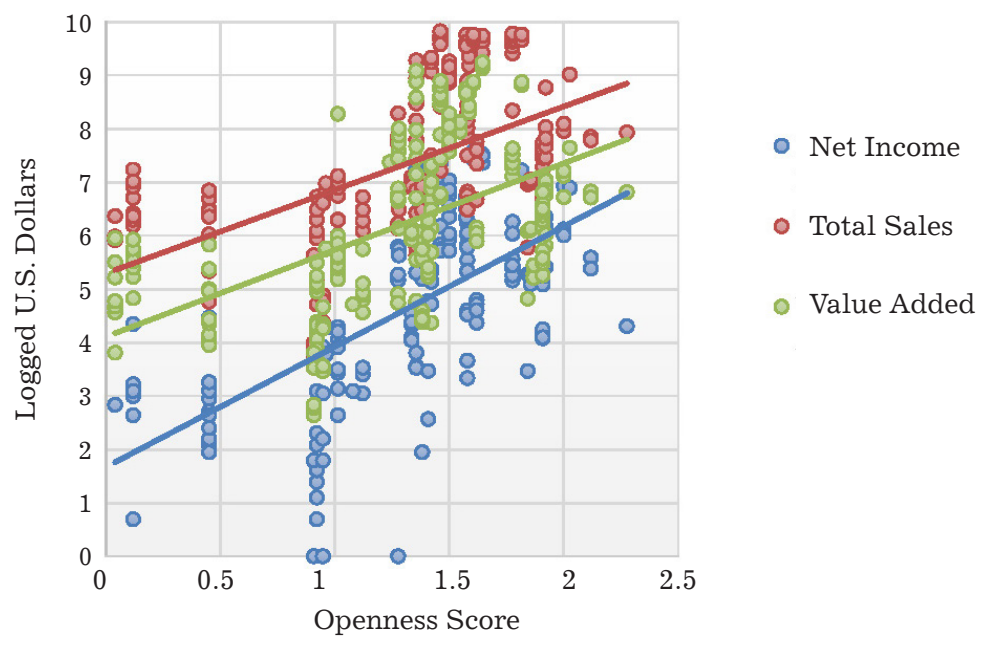

As demonstrated by Figure 4, affiliates in this sector tend to have greater net income and total sales when they resided in countries with greater openness of copyright user rights, and they tend to have more value added by their affiliates in these countries.

To control for other factors that ought to affect industry returns, we ran a series of regressions testing the relationship of openness to each of the three dependent variables: net income, total sales, and value added. In these regressions, GDP per capita and population control for the wealth and size of the national markets in which the affiliates operate, and fixed effects control for time. The results are presented in Table $3 .{ }^{37}$

Table 3: Regression results for NAIC 54 Professional, Scientific, and Technical Services

\begin{tabular}{|c|c|c|c|}
\hline \multirow[b]{2}{*}{ VARIABLES } & Dep. Var.: & Dep. Var.: & Dep. Var.: \\
\hline & $\begin{array}{l}\text { (Logged) } \\
\text { Net Income }\end{array}$ & (Logged) Total Sales & (Logged) Value Added \\
\hline \multirow[t]{2}{*}{ Openness Score } & $1.197 * * *$ & $0.286 * * *$ & $0.323 * * *$ \\
\hline & $(0.179)$ & $(0.0967)$ & $(0.0941)$ \\
\hline \multirow[t]{2}{*}{ (Logged) GDP per capita } & $1.104 * * *$ & $1.228 * * *$ & $1.287 * * *$ \\
\hline & $(0.101)$ & $(0.0672)$ & $(0.0600)$ \\
\hline \multirow[t]{2}{*}{ (Logged) Population } & $0.808 * * *$ & $0.798 * * *$ & $0.927 * * *$ \\
\hline & $(0.0658)$ & $(0.0402)$ & $(0.0388)$ \\
\hline \multirow[t]{2}{*}{ Constant } & $-21.47 * * *$ & $-18.51 * * *$ & $-22.44 * * *$ \\
\hline & $(1.809)$ & $(1.131)$ & $(0.989)$ \\
\hline Observations & 175 & 204 & 255 \\
\hline R-squared & 0.679 & 0.790 & 0.783 \\
\hline Time F.E. & Yes & Yes & Yes \\
\hline
\end{tabular}

Robust standard errors in parentheses

$* * * \mathrm{p}<0.01, * * \mathrm{p}<0.05, * \mathrm{p}<0.1$

${ }^{37}$ The coefficient on our openness score is positive and statistically significant at the $99 \%$ level of confidence for each of the three tests. The coefficients on the control variables are also positive and significant, as expected, and R2s between 0.67 and 0.79 indicate a good overall fit. Taken together, the results indicate that openness is associated with greater returns to foreign affiliates of U.S. firms in these industries, even when controlling for other factors that also affect returns (wealth, market size, and time). 


\section{The Impact of Openness on Traditional Copyright Industries}

We next sought out to test whether the gains to technology firms come at a cost to traditional copyright intensive industries - such as book publishers, music publishers, and motion picture and video producers. We find no evidence of such a cost.

We again use total revenue as the dependent variable, the openness score as the independent variable of interest, and the same set of controls. As shown in Table 4, there is no negative association between the openness of copyright limitations and revenues among the firms in our sample. Actually, there is a significant positive relationship between openness and revenues. We are not speculating the reason why - we only intend to demonstrate that there is no negative association between the two, and thus to show that openness in copyright limitations does not harm firms in these industries. ${ }^{38}$

TABLE 4: Firms that rely on copyright protection Dependent Variable: (Logged) Total Revenue

\begin{tabular}{|c|c|c|c|}
\hline \multirow{2}{*}{ VARIABLES } & \multicolumn{2}{|r|}{ (2) } & (3) \\
\hline & Book Publishers & Music Publishers & Motion Picture and Video Production \\
\hline \multirow[t]{2}{*}{ Openness } & $1.084 * * *$ & $2.607 * * *$ & $1.193 * * *$ \\
\hline & $(0.146)$ & $(0.822)$ & $(0.156)$ \\
\hline \multirow[t]{2}{*}{ (Log) Employment } & $0.861^{* * *}$ & $1.098 * * *$ & $1.021 * * *$ \\
\hline & $(0.0488)$ & $(0.144)$ & $(0.0360)$ \\
\hline \multirow[t]{2}{*}{ GDP per capita } & $3.93 \mathrm{e}-05^{* * *}$ & $7.69 \mathrm{e}-05^{* * *}$ & $1.16 \mathrm{e}-05^{* * *}$ \\
\hline & $(2.82 \mathrm{e}-06)$ & $(1.72 \mathrm{e}-05)$ & $(3.26 \mathrm{e}-06)$ \\
\hline \multirow[t]{2}{*}{ Population } & $1.58 \mathrm{e}-10$ & $1.63 \mathrm{e}-09 * * *$ & $-6.64 \mathrm{e}-10 * * *$ \\
\hline & $(2.01 \mathrm{e}-10)$ & $(5.48 \mathrm{e}-10)$ & $(1.49 \mathrm{e}-10)$ \\
\hline \multirow[t]{2}{*}{ Constant } & $10.24 * * *$ & $5.083 * *$ & $10.75 * * *$ \\
\hline & $(0.253)$ & $(2.114)$ & $(0.404)$ \\
\hline Observations & 504 & 60 & 504 \\
\hline R-squared & 0.748 & 0.900 & 0.766 \\
\hline Time FE & Yes & Yes & Yes \\
\hline
\end{tabular}

Robust standard errors in parentheses

$$
* * * \mathrm{p}<0.01, * * \mathrm{p}<0.05, * \mathrm{p}<0.1
$$

\section{The Impact of Openness on Scholarship}

Our final tests of copyright openness were directed at our hypothesis that more open copyright user rights would be of benefit to the creation of new works. We focused on works of scholarship both because of the relationship of scholarship to access to previous works and because of the availability of trend data over time. We find that more open copyright user rights are positively associated with the quantity and quality of scholarship production.

\footnotetext{
${ }^{38}$ In each regression, firm size and national wealth are positively associated with revenues, as expected. The R2 scores of 0.75 or over indicate a good overall fit. It is notable that our data source contains observations for fewer firms in this set of industries (especially music publishers), so our regressions involve smaller sample sizes. When we reran the tests on firms' net income instead of total revenue, the significant positive relationship between openness and revenues remained for all three industries. The control variables still behave as expected, though the number of observations fell.
} 
We obtained data on the number of citable documents produced by researchers in each country from the SCImago Journal \& Country Rank, which aggregates citations data from the Scopus database, which draws citation data from over 21,500 titles from more than 5,000 international publishers. ${ }^{39}$ Figure 5 shows the positive relationship between our openness score and research output as measured by citable documents.

Figure 5: Openness and Citable Documents

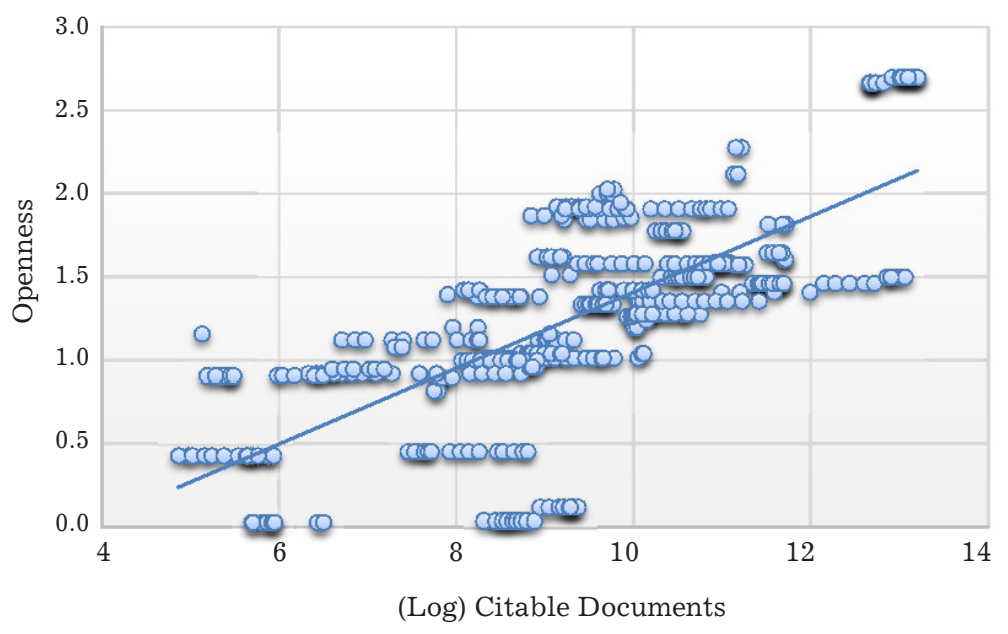

While the number of citable documents published by a country is an indicator of the quantity of scholarly output, it does not address the quality. To test the relationship between openness and the quality of scholarly output, we use the "H-index."This is the highest number of papers " $h$ "published by researchers in a given nation that have been cited at least $\mathrm{h}$ times. The metric was designed specifically to capture both the quantity and importance of a country's scholarly output, and is available from SciMag. Data on the H index is cumulative for the 1996-2005 periods, so annual observations are impossible.

Figure 6 shows a clear positive correlation between more open copyright user rights and higher scores on the $\mathrm{H}$-Index - indicating greater production of more heavily cited works.

Figure 6: Openness and H-Index

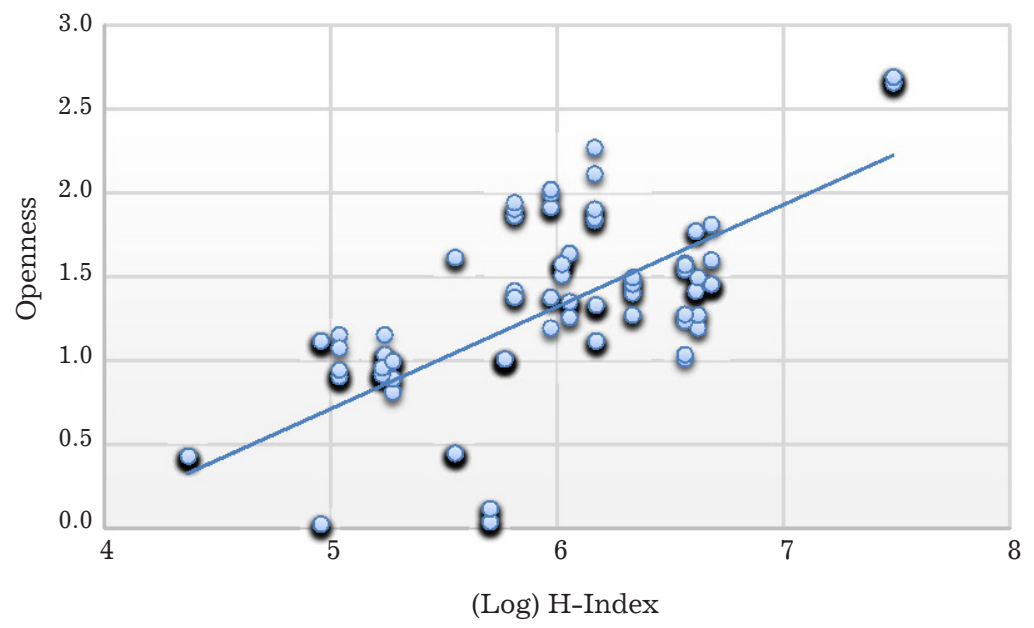

${ }^{39}$ The citable documents, data, and other citations data including the $\mathrm{H}$ index, is available for download from Scimago at http://www.scimagojr. com. 
To test these relationship while controlling for national wealth, population and time, we regress these two citations metrics against our openness variable, GDP per capita, population, and time-fixed effects. Table 5 demonstrates the correlations between openness and both citations metrics remain highly statistically significant when we control for these other factors. ${ }^{40}$

TABLE 5: Scholarly Output Dependent Variables: (1) Citable Documents, and (2) H-Index

\begin{tabular}{|c|c|c|}
\hline \multirow{2}{*}{ VARIABLES } & \multicolumn{2}{|l|}{ (1) } \\
\hline & Citable Documents & H-Index \\
\hline \multirow[t]{2}{*}{ Openness } & $1.248^{* * *}$ & $0.394 * * *$ \\
\hline & $(0.121)$ & $(0.0438)$ \\
\hline \multirow[t]{2}{*}{ GPD per capita } & $0.0369 * * *$ & $0.0219^{* * *}$ \\
\hline & $(0.00304)$ & $(0.000904)$ \\
\hline \multirow[t]{2}{*}{ Population } & $2.54 \mathrm{e}-09 * * *$ & $6.96 \mathrm{e}-10^{* * *}$ \\
\hline & $(1.11 \mathrm{e}-10)$ & $(2.63 \mathrm{e}-11)$ \\
\hline \multirow[t]{2}{*}{ Constant } & $6.541 * * *$ & $4.821^{* * *}$ \\
\hline & $(0.162)$ & $(0.0577)$ \\
\hline Observations & 396 & 396 \\
\hline R-squared & 0.725 & 0.801 \\
\hline Time F.E. & Yes & Yes \\
\hline
\end{tabular}

Robust standard errors in parentheses

$$
* * * \mathrm{p}<0.01, * * \mathrm{p}<0.05, * \mathrm{p}<0.1
$$


here is a new open access resource for researchers seeking to test the impact of user rights on society - the User Rights Database.

Our tests using the openness score from the Database provide empirical evidence that greater openness in copyright user rights is associated with positive outcomes. Firms in the software, computer systems design and contract research and development industries earned higher revenues when operating in countries with more open copyright limitations. Similarly, information sector firms earned higher returns. On the other hand, publishers of books, music, and film did not suffer adverse consequences as these countries became more open. We also find that scholars in countries with more open user rights environments publish more papers, and publish more highly cited papers.

Although there is a general trend toward more open copyright user rights in our data, we observe a large and growing gap between the openness of copyright limitations in low/middle- and high-income countries. This indicates a role for both domestic legislatures and the international architecture in promoting and protecting more open copyright user rights.

Our work has not proved that adopting more open user rights, such as the U.S. fair use clause, will lead directly to improvements in innovation and creativity. The scope of user rights is unlikely to be such a powerful policy tool so as to overcome all barriers in other areas of law, policy, and society that can hamper social and economic development. But user rights are policy tools - ones that should be used consciously to promote the ends of society. 
USER RIGHTS ARE POLICY TOOLS, WHICH

SHOULD BE USED CONSCIOUSLY TO PROMOTE THE ENDS OF SOCIETY.

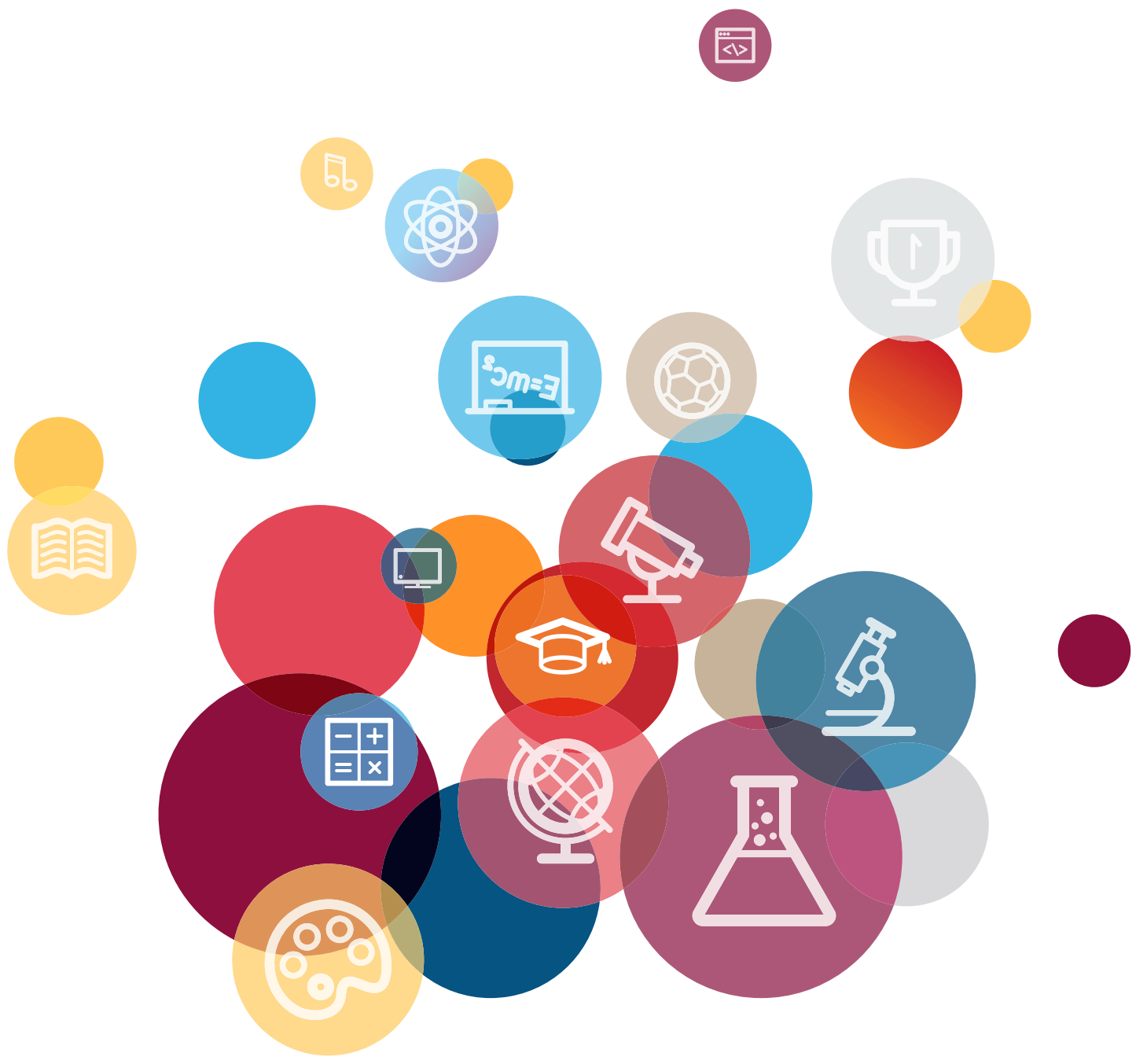




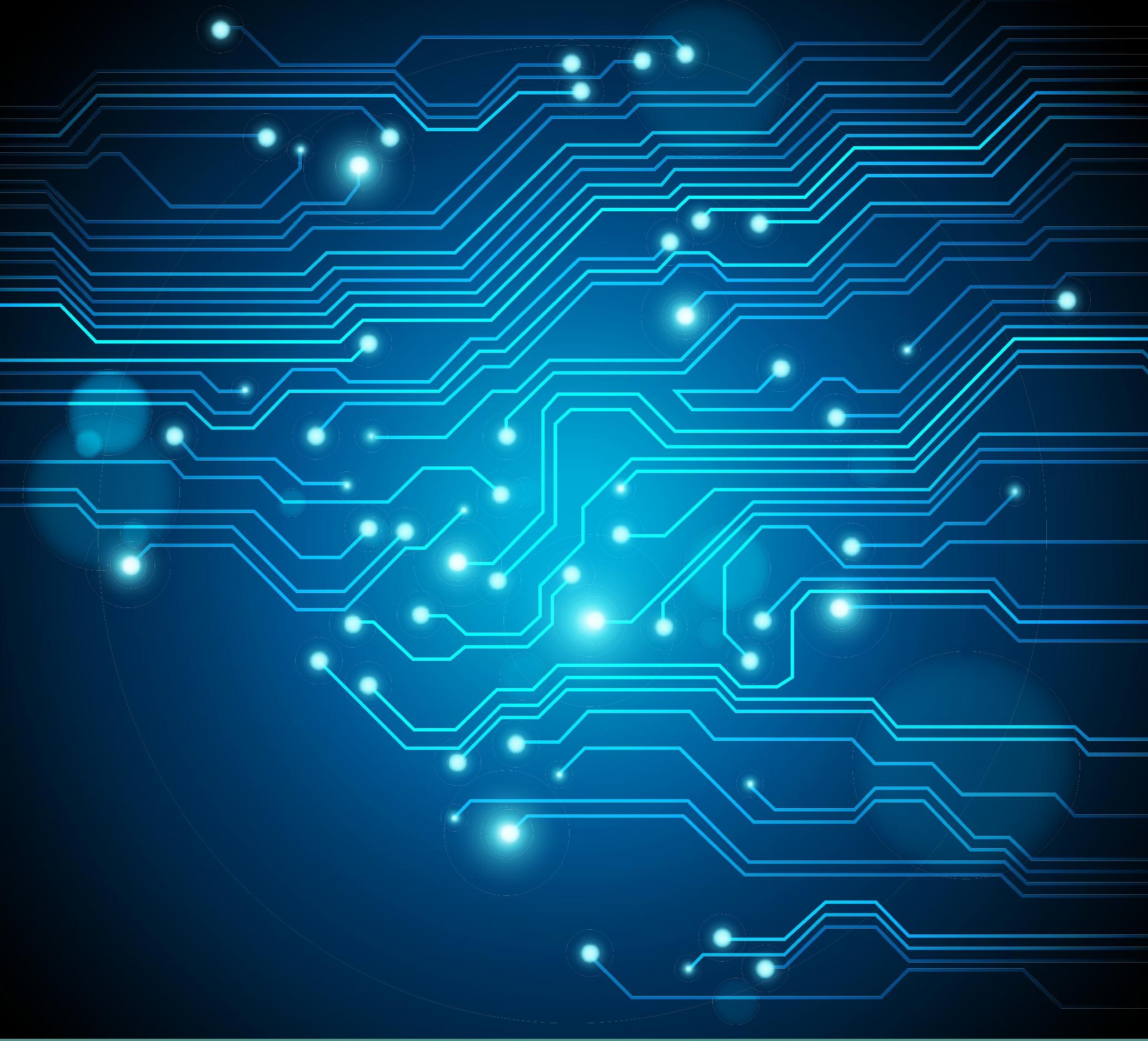

This report is a product of

The Global Expert Network on Copyright User Rights

http://infojustice.org/flexible-use

The Global Expert Network is coordinated by

Program on Information Justice and Intellectual Property

American University Washington College of Law

4300 Nebraska Ave NW

Washington D.C. 20016

www.pijip.org 